\title{
Diuretic and hipotensive activity of aqueous extract of parsley seeds (Petroselinum sativum Hoffm.) in rats
}

\author{
Kleber Eduardo de Campos, ${ }^{* 1}$ Ana Paula Coelho Balbi, ${ }^{2}$ Maria José Queiroz de Freitas Alves \\ ${ }^{1}$ Departamento de Ginecologia e Obstetrícia, Faculdade de Medicina de Botucatu - UNESP, Distrito de Rubião \\ Júnior, s/n, 18618-000, Botucatu-SP, Brazil, \\ ${ }^{2}$ Instituto de Ciências Biomédicas, Universidade Federal de Uberlândia, Avenida Pará, 1720, \\ Umuarama, 38400-902, Uberlândia-MG, Brazil, \\ ${ }^{3}$ Departamento de Fisiologia, Instituto de Biociências, Universidade Estadual Paulista Júlio de Mesquita Filho, \\ Campus Rubião Jr, 18618-000 Botucatu-SP, Brazil
}

\begin{abstract}
RESUMO: "Atividade diurética e hipotensora do extrato aquoso da semente de salsa (Petroselinum sativum Hoffm.) em ratos". A espécie vegetal, Petroselinum sativum Hoff, conhecida como salsa, é amplamente utilizada na medicina popular brasileira como diurético. O objetivo desse estudo é verificar se o uso brasileiro do extrato aquoso da salsa tem efeitos semelhantes com investigações que mostram o efeito diurético da $P$. sativum em ratos. Métodos: 19 ratos foram anestesiados e canulamos a traquéia, artéria carótida esquerda (para a medição da pressão arterial) e bexiga urinária (para coletar urina). Depois de 40 minutos para adaptação das condições cirúrgicas, ratos anestesiados foram administrados de acordo com seus grupos: controle $(\mathrm{CON})$, administração oral com $1.0 \mathrm{~mL}$ de água filtrada, e grupo tratado (AE), administração oral com extrato aquoso de sementes de salsa 20\% (AE). Urina foi coletada três vezes (de 30 em 30 minutos) e então esse material foi utilizado para determinações de sódio e potássio, para avaliar a quantidade excretada desses íons. Pressão arterial foi medida pelo manômetro de mercúrio por 9 vezes. Todos os dados foram estatisticamente avaliados. Resultados e conclusão: nos parâmetros anestesiados, o grupo CON não mostrou nenhuma diferença; mas o grupo AE mostrou um aumento do fluxo urinário e da quantidade excretada de sódio e potássio, e também uma diminuição da pressão arterial. Todos os parâmetros apresentaram essas modificações após 30 minutos de administração do $\mathrm{AE}(\mathrm{p}<0,05)$. Esses resultados mostram que o tratamento com o AE leva a efeitos natriurético e hipotensor em ratos Wistar anestesiados, confirmando o uso da população brasileira dessa erva como diurético.
\end{abstract}

Unitermos: Petroselinum sativum, Umbelliferae, salsa, efeito diurético, efeito hipotensor.

\begin{abstract}
Purpose: the vegetal specie, Petroselinum sativum Hoff., known as parsley, is widely used in the Brazilian folk medicine as diuretic. The objective of this study is to verify if Brazilian use of parsley aqueous extract has similar effects with investigations that show a diuretic effect of P. sativum in rats. Methods: 19 rats were anesthetized and we cannulated the trachea, left carotid artery (for arterial pressure measurement) and urinary bladder (to collect urine). After 40 minutes of adaptive surgery conditions, anesthetized rats were administrated as related with their group: control $(\mathrm{CON})$, oral administration with $1.0 \mathrm{~mL}$ of filtered water, and treated group (AE), oral administration with aqueous extract of seeds of parsley $20 \%$ (AE). Urine was collected three times (30 minutes each) and then this material was used for sodium and potassium determinations, to evaluate the amount excreted of these ions. Blood pressure was measured by mercury manometer for 9 times. All data were statistically evaluated. Results and conclusion: in the analyzed parameters, CON group did not show any differences; but AE group showed an increased of urinary flow and sodium and potassium amount excreted, and also decreased arterial pressure. All the parameters presented these modifications after 30 minutes of administration of $A E(p<0.05)$. These results show that the treatment with the AE results in natriuretic and hypotensive effects in anesthetized Wistar rats, confirming the use of Brazilian population of this herb as diuretic.
\end{abstract}

Keywords: Petroselinum sativum, Umbelliferae, parsley, diuretic effect, hypotensive effects.

\section{INTRODUCTION}

Plants have been utilized as medicine throughout human story and probably even before humans involved, given the practice of botanical medicine by nonhuman animals. Among the many applications of herbs in medicine include the use of these agents to treat conditions of the urinary tract (Yarnell, 2002). 
Parsley is widely used by Brazilian population, as a remedy for many different ailments (Brandão et al., 2006; Carlini et al., 2006; Oliveira et al., 2007). In addition to its recognized role as antioxidant (Fejes et al., 1998; Ozoy-Sacan et al., 2006), anti-inflammatory, calcium-channel-blocker in intestine and uterus muscle (Neuhaus-Carlisle et al., 1993), cancer preventive agent (Zheng et al., 1992) laxative properties (Kreyydieh et al., 2001), antiulcerogenic (Al-Howinry et al., 2003) and hypoglycemic (Yanardag et al., 2003; Ozoy-Sacan et al., 2006), the herb has gained also a wide reputation as a powerful diuretic in Europe (Tyler, 1993; Anderson et al., 1996), Africa (Watt \& Breyer-Branddwijk 1962) and Brazil (Alzugaray \& Alzugaray, 1983; Vieira, 1992).

Several data from WHO (World Health Organization) show $80 \%$ of world population has already used any plant as therapeutics. From these $80 \%$, at least $30 \%$ utilized medicinal plants from clinical indication (Martins et al., 1992). The utilization of medicinal plants is more common in underdeveloped countries, as in Brazil (Heck et al., 2000). Brazilian science is advancing to study the medicinal plants properties, because is widely used in the population, and Brazilian flora is much diversified and also this country is known as the most active principles sources of the planet (Savastano \& DiStasi, 1996; Barbosa-Filho et al., 2007, 2008; Biavatti et al., 2007; Corrêa et al., 2008; Sousa et al., 2008).

Although the scientific role of parsley in diuresis is already recognized and documented, there is no data about Brazilian culture influence of this herb in urinary tract and blood pressure. Therefore, the aim of this investigation is to study if Brazilian use of parsley aqueous extract, widely used in this country by folk medicine, has similar effects with investigations that show a diuretic effect of $P$. sativum in rats.

\section{MATERIAL AND METHODS}

Male Wistar rats weighing $230 \pm 10 \mathrm{~g}$ were adapted in the Department of Physiology, for seven days. The rats were kept in collective cages in controlled conditions of temperature $\left(22 \pm 3{ }^{\circ} \mathrm{C}\right)$, light $(12 \mathrm{~h}$ light/ dark cycle) and relative humidity $(60 \pm 5 \%)$. The animals were fed with laboratory chow (Purina ${ }^{\circledR}$ ) and tap water ad libitum. All experimental procedures of this study were approved by the Committee of Ethics in Animal Experimentation at the Biosciences Institute - Unesp Campus de Botucatu, State of São Paulo, Brazil.

The herb used was Petroselinum sativum Hoffm., very common in Brazil. It was cultivated on autumn $(\mathrm{n}=09)$ at the Department of Physiology and identified by BOTU herbarium (serial number 23134). Parsley seeds were harvested between 8:00 and 9:30 am, and the aqueous extract (AE) prepared at the beginning of each experiment: as used by related in brazilian medicine folk, $\mathrm{AE}$ was prepared as a tea $(20 \mathrm{~g}$ of parsley seeds in $100 \mathrm{~mL}$ of boiled water, for 5 minutes) (Alzugaray \&
Alzugaray, 1983; Vieira, 1992).

The animals were separated into two experimental groups. In control group (CON), by intragastric way, rats $(\mathrm{n}=10)$ received $1.0 \mathrm{~mL}$ of water; whereas in the treated group (AE), rats $(\mathrm{n}=09)$ received $1.0 \mathrm{~mL}$ of aqueous extract of parsley, at the same administration way.

The experimental procedure was followed by protocol suggested by Malnic \& Marcondes, 1986 (Malnic \& Marcondes, 1986). Rats were anesthetized by i.p. injection of pentobarbital ( $5 \mathrm{mg} / 100 \mathrm{~g}$ body weight). The animals were put in a surgery table and, the trachea and left carotid were cannulated by opening incision of the area. Another incision was prepared in the region of the bladder, so this structure was also cannulated by surgery. These cannulas were adapted in rats for better ventilation (trachea), arterial pressure measures (left carotid) and urine collect (bladder). The rats were maintained anesthetized throughout all the experiment, that is composed by three phases: adaptation, $A d$ (animal adaptation to experimental conditions, 40 minutes), basal, $B$ (basal parameters evaluation, 30 minutes) and experimental, $E x$ (pos-treating parameters evaluation, 90 minutes). Experimental phase is also divided into three subphases (Ex1,Ex2 and Ex3, 30 minutes each) (Table 1).

Urinary volume vas collected at the end of each experimental period by bladder cannula $(B, E x 1, E x 2$ and $E x 3)$. Urinary flow was calculated and the material was freezed for further sodium and potassium determinations. Arterial pressure variations (AP) were measured by left carotid cannula connected with a manometer with mercury form 10 to 10 minutes since the phase $B$ until the end of the experiment. At the end of the experiment, all the anesthetized animals were killed (Table 1).

Sodium and potassium concentrations were evaluate by flame photometry. Sodium $\left(\mathrm{Qe}_{(\mathrm{Na}}{ }^{+}\right)$and potassium $\left(\mathrm{Qe}_{\left(\mathrm{K}^{+}\right)}\right)$amount excreted were calculated in $\mathrm{uEq} / \mathrm{min}$ (Malnic \& Marcondes, 1986). To compare AEtreated rats data with their respective control group and to compare Experimental phase with the Basal phase on the same group, the parameters were statistically evaluated using the Analysis of Variance (ANOVA) followed by Test of Multiple Comparisons of Tukey, and the limit of statistical significance was 5\% $(\mathrm{p}<0.05)$ (Vieira, 1997).

\section{RESULTS}

Results are shown in Table 2, as means \pm SEM, to compare all parameters in the basal and experimental phases of the same group and also to compare statistical differences of parameters of the same basal and experimental phases in different groups.

The animals of CON group did not present any significant differences in all parameters evaluated ( $>0.05)$, but parsley AE-treated rats presented significant modifications $(\mathrm{p}<0.05)$ in all parameters evaluated $(E x 2$ and Ex3 periods), compared with CON group. Parsley increased urinary flow, $\mathrm{Qe}_{(\mathrm{Na}}{ }^{+}$) and $\mathrm{Qe}_{(\mathrm{K}}{ }^{+}$, and also decreased blood pressure (Table 2) 
Table 1. Experimental protocol with three phases, adaptation, basal and experimental (with three subphases).

\begin{tabular}{l|c|c|c|c|c}
\hline Phases & Adaptation & Basal & \multicolumn{3}{|c}{ Experimental } \\
\hline Abbreviation & $A d$ & $B$ & $E x 1$ & Ex2 & Ex3 \\
\hline Time & $40 \mathrm{~min}$ & $30 \mathrm{~min}$ & $30 \mathrm{~min}$ & $30 \mathrm{~min}$ & $30 \mathrm{~min}$ \\
\hline Urinary flow $(\mathrm{uL} / \mathrm{min})$ & $\mathrm{X}$ & 1 time & 1 time & 1 time & 1 time \\
\hline $\begin{array}{l}\text { Blood pressure } \\
(\mathrm{mmHg})\end{array}$ & $\mathrm{X}$ & $\begin{array}{c}3 \text { times } \\
(10 / 10 \mathrm{~min})\end{array}$ & $\begin{array}{c}3 \text { times } \\
(10 / 10 \mathrm{~min})\end{array}$ & $\begin{array}{c}3 \text { times } \\
(10 / 10 \mathrm{~min})\end{array}$ & $\begin{array}{c}3 \text { times } \\
(10 / 10 \mathrm{~min})\end{array}$ \\
\hline
\end{tabular}

Table 2. Renal parameters and blood pressure from control (CON) and Petroselinum sativum aqueous extract treated-rats (AE).

\begin{tabular}{|c|c|c|c|c|c|c|c|c|}
\hline \multirow{2}{*}{$\begin{array}{l}\text { Groups } \\
\text { Experimental phases }\end{array}$} & \multicolumn{4}{|c|}{$\operatorname{CON}(n=10)$} & \multicolumn{4}{|c|}{$\mathrm{AE}(\mathrm{n}=9)$} \\
\hline & $B$ & Exl & $\operatorname{Ex} 2$ & Ex3 & $B$ & Exl & $\operatorname{Ex2}$ & Ex3 \\
\hline Urinary flow $(\mu \mathrm{L} / \mathrm{min})$ & $3.2 \pm 1.1$ & $3.1 \pm 1.0$ & $2.7 \pm 1.0$ & $2.4 \pm 1.0$ & $3.9 \pm 0.6$ & $3.7 \pm 0.8$ & $4.6 \pm 1.2^{*}$ & $5.1 \pm 1.0 * \#$ \\
\hline$\left(\mathrm{Qe}_{(\mathrm{Na}}+\right)(\mathrm{mEq} / \mathrm{min})$ & $0.34 \pm 0.12$ & $0.30 \pm 0.10$ & $0.21 \pm 0.05$ & $0.20 \pm 0.05$ & $0.29 \pm 0.05$ & $0.27 \pm 0.07$ & $0.41 \pm 0.05^{*}$ & $0.51 \pm 0.06^{* \#}$ \\
\hline$\left(\mathrm{Qe}_{(\mathrm{K}}{ }^{+}\right)(\mathrm{mEq} / \mathrm{min})$ & $0.49 \pm 0.16$ & $0.45 \pm 0.15$ & $0.42 \pm 0.18$ & $0.37 \pm 0.15$ & $0, .6 \pm 0.09$ & $0.68 \pm 0.15$ & $0.89 \pm 0.18^{*}$ & $1.51 \pm 0.29^{* \#}$ \\
\hline $\mathrm{AP}(\mathrm{mmHg})$ & $100.37 \pm 17.44$ & $100.27 \pm 19.30$ & $90.91 \pm 22.71$ & $90.69 \pm 23.72$ & $100.89 \pm 14.76$ & $100.66 \pm 15.66$ & $90.04 \pm 14.41$ & $70.39 \pm 11.05 * \#$ \\
\hline
\end{tabular}

Values expressed as mean \pm standard deviation.

* significant difference compared to respective control group ( $\mathrm{p}<0.05$ - ANOVA followed by Tukey Multiple Comparisons Test).

\# significant difference compared to basal phase $(B)$ ( $\mathrm{p}<0.05$ - ANOVA followed by Tukey Multiple Comparisons Test).

When comparing the Experimental phase with their respective Basal phase, there was statistically differences in Ex3 of all parameters of the AE group $(p<0.05)$ : parsley increased, after 1 hour of administration, urinary flow, $\mathrm{Qe}_{\left(\mathrm{Na}^{+}\right)}+$and $\mathrm{Qe}_{(\mathrm{K}}+$, and decreased blood pressure (Table 2).

\section{DISCUSSION}

No trials have definitely proven the mechanism of action of diuretic herbs in humans. The late pharmacognocist, Varro Tyler, $\mathrm{PhD}$, theorized that herbs act only as aquaretics, or agents that increase water excretion without affecting renal handling of electrolytes (Tyler, 1994). Aquaretics may work by causing dilation of glomerular arterioles, thereby increasing glomerular filtration rate. Since water intake can itself have aquaretic effects, and many aquaretic herbs are taken as teas, this would partially explain variable results of clinical trials with aquaretic herbs. (Schilcher, 1987a,b). The results of this experiment do not follow aquaretic theory, because both experimental groups were orally treated with the same volume $(1.0 \mathrm{~mL})$.

In general, our results confirm with other experiments. Existing data do not support the aquaretic theory, however. Repeatedly, diuretic herbs have been shown to influence renal electrolyte handling, particularly sodium and potassium, and thus have diuretic activity (Pantoja et al., 2000; Yarnell, 2002; Galati et al., 2002).

Kreydiyyeh \& Usta, 2002 studied two associated parsley species, Petroselinum hortense Hoffm. and Petroselinum sativum Hoffm., and these herbs leads an increase of 24-h urinary volume These results are according with our study, the Brazilian parsley (Petroselinum sativum Hoffm.) also promoted a diuretic state on the AE-treated animals.

Diuretic state can be a consequence of an increased renal sodium excretion (natriuresis). In Table 2, data showed that $\mathrm{AE}$ leads an increase renal excretion of sodium and water, presented on two last subphases of Experimental phase (Ex2 and Ex3). The herb may lead these alterations 30 minutes after its administration. Kreydiyyeh \& Usta, 2002 showed a test with parsley extract added to a sodium-free perfusion buffer in rats. The urine flow rate was in this case, significantly higher than the one observed with the sodium-free buffer. It can suggest that parsley does not affect $\mathrm{Na}^{+}$transport, since its effect was not dependent on its presence, or it is, it has an addition another site of action. This herb could be inhibiting sodium reabsorption through another mechanism that involves neither the $\mathrm{Na}^{+} / \mathrm{H}^{+}$exchanger nor $\mathrm{NaKCl}_{2}$ transporter, leading to more sodium and consequently more water retention in the tubes.

Urinary flow is directly related with potassium secretion. The same cited study, reported by Kreyydieh \& Usta (2002), shows that the diuretic effect of parsley AE treatment in rats seems thus to be mediated though a change in potassium transport. Parsley may be inhibiting potassium absorption or stimulating potassium secretion, or both, leading, in either case, to more potassium retention in the lumen of the kidney tubules and osmotic water flow (caliuresis). Like sodium results, in our experiment parsley leads a caliuresis state in 30 minutes after administration (Table 2).

This experiment also evaluated arterial pressure (AP) alterations throughout the treatment. In Table 2, parsley acted as hypotensive effect, decreasing AP on treated rats. AP control is complex and several mechanisms can influence, as neural, hormonal and renal. Kidney is known as an AP regulator organ, because it 
promotes water and salt excretion and so this mechanism can regulate volume and AP (Campos et al., 2005). AE treatment decreased $30 \%$ pressure levels at the end of the experiment (one hour after $\mathrm{AE}$ oral administration); this effect was found together with a natridiuresis effect, at the same moments of the experiment (EX2 and $E x 3$ subphases). Therefore, the hypotensive effect found in this experiment (Table 2) suggests, in part, that is conducted by water and salt renal excretions alterations.

Thus, it is concluded that parsley was responsible for the appearance of natridiuretic and hypotensive effect. This study confirmed the use of parsley tea as diuretic by Brazilian folk medicine, because this herb corroborates other studies, presenting renal and pressure alterations, confirming the diuretic effect in rats. Although we do not yet totally understand which active principle and its mechanism of action causes these effects, the use of animal models suggest a wide variety of possibilities. Our laboratory still investigates some renal mechanisms, for better understanding these renal and cardiovascular modifications.

\section{ACKNOWLEDGEMENTS}

The authors thank to Hildebrando Luiz da Silva, BOTU Herbarium, Department of Botany, and Mr. Antônio Carlos de Barros Tardivo, Laboratory of Kidney and Biomembranes, Department of Physiology for all technical assistance.

\section{REFERENCES}

Al-Howiniry T, Al-Sohaibani M, El-Tahir K, Rafatullah S 2003. Prevention of experimentally-induced gastric ulcers in rats by an ethanolic extract of "parsley", Petroselinum crispum. Am J Chim Med 31: 699-711.

Alzugaray D, Alzugaray C 1983. Cebola. In: Alzugaray, D. (org) Plantas que curam. v.10. Rio de Janeiro: Editora Três, p.135-6.

Anderson LA, Newall CA, Phillipson JD 1996. Herbal Medicine. In: Anderson, L.A.; Newall, C.A.; Phillipson, J.D. (org) A Guide for Health-care professionals. $1^{\text {st }} \mathrm{ed}$. London: The Pharmaceutical Press; p.203-4.

Barbosa-Filho JM, Nascimento-Júnior FA, Tomaz ACA, Athayde-Filho PF, Silva MS, Cunha EVL, Souza MFV, Batista LM, Diniz MFFM 2007. Natural products with antileprotic activity. Rev Bras Farmacogn 17: 141148.

Barbosa-Filho JM, Alencar AA, Nunes XP, Tomaz ACA, Sena-Filho JG, Athayde-Filho PF, Silva MS, Souza MFV, da-Cunha EVL 2008. Sources of alpha-, beta, gamma-, delta- and epsilon-carotenes: A twentieth century review. Rev Bras Farmacogn 18: 135-154.

Biavatti M, Marensi V, Leite SN, Reis A 2007. Ethnopharmacognostic survey on botanical compendia for potential cosmeceutic species from Atlantic Forest. Rev Bras Farmacogn 17: 640-653.

Brandão MGL, Cosenza GP, Moreira RA, Monte-Mor RLM 2006. Medicinal plants and other botanical products from the Brazilian Official Pharmacopoeia. Rev Bras Farmacogn 16: 408-420.

Campos KE, Balbi APC, Alves MJQF 2005. Efeitos do extrato aquoso de cebola (Allium cepa L.) sobre a função renal e a pressão arterial em ratos Wistar. Rev Bras $P l$ Med 8: 24-27.

Carlini EA, Rodrigues E, Mendes FR, Tabach R, Gianfratti B 2006. Treatment of drug dependence with Brazilian herbal medicines. Rev Bras Farmacogn 16: 690-695.

Corrêa MFP, Melo GO, Costa SS 2008. Substâncias de origem vegetal potencialmente úteis na terapia da Asma. Rev Bras Farmacogn 18 (Supl.): 785-797.

Fejes S, Kery A, Blazovics A, Lugasi A, Lemberkovics E, Petri G, Szoke E 1998. Investigation of the in vitro antioxidant effect of Petroselinum crispum (Mill.) Nym. ex A.W. Hill. Acta Pharmacol Hung 68: 150156.

Galati EM, Tripodo MM, Trovato A, Miceli N, Monforte MT 2002. Biologic effect of Opuntia ficus indica (L) Mill (Cactaceae) waste matter. Note I: diuretic activity. $J$ Ethnopharmacol 79: 17-21.

Heck AM, DeWitt BA, Lukes AL 2000. Potential interactions between alternative therapies and warfarin. $A m J$ Health-Syst Pharm 57: 1221-1227.

Kreyydieh SI, Usta J, Kaouk I, Al-Sadi R 2001. The mechanism underlying the laxative properties of parsley extract. Phytomedicine 8: 382-388.

Kreyydieh SI, Usta J 2002. Diuretic effect and mechanism of action of parsley. J Ethnopharmacol 79: 353-357.

Malnic G, Marcondes M 1986. Fisiologia renal. 3aed. São Paulo. EDART - São Paulo - Livraria Editora Ltda.

Martins ER, Mitsugui SY, Silvia AV 1992. Da colheita a comercialização. In: Martins, E.R. (org) Plantas Medicinais. $1^{\mathrm{a}} \mathrm{ed}$. Viçosa, Departamento de Fitotecnia / Universidade Federal de Viçosa, p.1-27.

Neuhaus-Carlisle K, Vierling W, Wagner H 1993. Calciumchannel blocking activity of essencial oils from Petroselinum crispum, Apium graveolens and isolated phenylpropane constituents. Pharm Pharmacol Lett 3: 77-79.

Oliveira FQ, Gobira B, Guimarães C, Batista J, Barreto M, Souza M 2007. Espécies vegetais indicadas na odontologia. Rev Bras Farmacogn 17: 466-476.

Ozoy-Sacan O, Yanardag R, Orak H, Ozgey Y, Yarat A, Tunali T 2006. Effects of parsley (Petroselimum crispum) extract versus glibornuride on the liver os streptozotocininduced diabetic rats. J Ethnopharmacol 104: 175181.

Pantoja CV, Martin NT, Norris BC, Contreras CM 2000. Purification and bioassays of a diuretic and natriuretic fration from garlic (Allium sativum). $J$ Ethnopharmacol 70: 35-40.

Savastano MAP, DiStasi LC 1996. Folclore: conceitos e metodologia. In: DiStasi, L.C. (org) Plantas Medicinais: Arte e Ciência: Um Guia de Estudo Interdisciplinar. $1^{\text {a }}$ ed. São Paulo: Editora Unesp, p.3745.

Schilcher H 1987a. Moglichkeiten und grenzen der phytotherapie am beispiel pflanzlicher urologika. Urologe B 27: 316-319.

Schilcher H 1987b. Pflanzlicher diuretika. Urologe B 27: 215222.

Sousa FCF, Melo CTV, Citó MCO, Félix FHC, Vasconcelos 
SMM, Fonteles MMF, Barbosa-Filho JM, Viana GSB 2008. Plantas medicinais e seus constituintes bioativos: Uma revisão da bioatividade e potenciais benefícios nos distúrbios da ansiedade em modelos animais. Rev Bras Farmacogn 18: 642-654.

Tyler VE 1993. The honest herbalist. $3^{\text {rd }}$ ed. New York: Pharmaceutical Products Press.

Tyler VE 1994. Herbs of choice: the therapeutic use of phytomedicinals. New York: Pharmaceutical Products Press, Binghampton.

Vieira LS 1992. Plantas medicinais de uso popular: salsa, salsahortense, salsinha. In: Vieira, L.S. (org) Fitoterapia da Amazônia: manual de plantas medicinais. $2^{\mathrm{a}} \mathrm{ed}$. São Paulo: Editora Agronômica Ceres, p.199-201.

Vieira S 1997. Outros delineamentos. In: Vieira, S. (org) Estatística Experimental. $1^{\text {a }}$ ed. São Paulo: Atlas, p.119-132.

Watt JM, Breyer-Brandwijk MG 1962. Parsley, Petroselinum sativum Hoff. In: Watt, J. M.; Breyer-Brandwijk, M.G. (org) The Medicinal and Poisonous Plants of Southern and Eastern Africa. $1^{\text {st }}$ ed. Edinburg: Ed. Livington, p.671-4.

Yanardag R, Bolkent S, Tabakoglu-Ogluz A, Ozoy-Sacan O 2003. Effects os Petroselinum crispum extract on pancreatic B cells and blood glucose of streptozotocininduced diabetic rats. Biol Pharm Bull 26: 1206-1210.

Yarnell E 2002. Botanical medicines for the urinary extract. World J Urology 20: 285-293.

Zheng GQ, Kenney PM, Zhang J, Lam LK 1992. Inhibition of benzo[a]pyrene-induced tumorigenesis by myristicin, a volatile aroma constituent of parsley leaf oil. Carcinogenesis 13: 1921-1923. 